\title{
HAK ASASI MANUSIA (HAM) DAN DEMOKRASI DI INDONESIA
}

\author{
Haneifa Hebatullah \\ IIK Surya Mitra Husada Indonesia \\ $\underline{\text { haniefa.hebatullah@gmail.com }}$
}

\begin{abstract}
Abstrak
Negara demokrasi adalah negara yang menganut bentuk atau mekanisme sistem pemerintahan dengan mewujudkan kedaulatan rakyat atas negara untuk dijalankan oleh pemerintah negara tersebut. Indonesia sendiri menganut demokrasi pancasila yaitu demokrasi berdasarkan kekeluargaan dan gotong - royong yang ditujukan kepada kesejahteraan rakyat, yang mengandung unsur - unsur kesadaran religius, berdasarkan kebenaran, kecintaan dan budi pekerti luhur, berkepribadian Indonesia dan berkesinambungan. Perjuangan menegakkan demokrasi merupakan upaya umat manusia dalam rangka menjamin dan melindungi hak asasinya, karena demokrasi merupakan salah satu sistem politik yang memberi penghargaan atas hak dasar manusia. Dalam suatu Negara yang berdemokrasi, Implementasi Hak Asasi Manusia merupakan suatu keharusan. Demokrasi bukanlah hanya sebatas hak sipil dan politik rakyat, namun dalam perkembangannya demokrasi juga terkait erat dengan sejauh mana terjaminnya hak-hak ekonomi dan sosial budaya dari rakyatnya. Dengan demikian hak asasi manusia akan terwujud dan terjamin oleh negara yang demokratis dan demikian sebaliknya, demokrasi akan terwujud apabila negara mampu menjamin tegaknya hak asasi manusia.
\end{abstract}

\section{Latar Belakang}

Hak Asasi Manusia adalah seperangkat hak yang melekat pada hakikat dan keberadaan manusia sebagai mahkluk Tuhan Yang Maha Esa dan merupakan anugerah-Nya yang wajib dihormati, dijunjung tinggi, dan dilindungi oleh negara, hukum, Pemerintah, dan setiap orang demi kehormatan serta perlindungan harkat dan martabat manusia. Hak asasi manusia dan demokrasi dapat dimaknai sebagai hasil perjuangan manusia untuk mempertahankan dan mencapai harkat kemanusiaannya, sebab hingga saat ini hanya konsepsi hak asasi manusia dan demokrasilah yang terbukti paling mengakui dan menjamin harkat kemanusiaan. Negara disini secara demokratis berkewajiban untuk mengeluarkan segala peraturan perundangan dan instrumen hukum lainnya agar pelaksanaan hak asasi manusia dapat ditegakkan secara demokratis sesuai dengan aturan yang berlaku. Salah satu hak dasar warga Negara adalah hak demokrasi dan kebebasan atas penyelenggaraan, pemenuhan, dan penggunaan hak demokrasi itu sendiri. Hak tersebut merupakan bagian yang sangat penting dalam perjalanan kebangsaan mengingat upaya demokratisasi yang bermuara kepada kebebasan demokrasi tersebut dari waktu ke waktu terus mengalami perkembangan.

Keberadaan Hak Asasi Manusia dalam konsepsi Negara hukum tersebut bukan berarti terjadinya pengekangan hak asasi manusia oleh Negara, namun dalam konsepsinya adalah pengaturan oleh Negara. Berkaitan dengan hal tersebut menurut Bahder Johan Nasution: Dilihat dari sudut pandang pengaturan hak asasi manusia, pada satu sisi hak asasi memiliki 
sifat dasar yang membatasi kekuasaan pemerintahan, namun sebaliknya pada sisi lain pemerintah diberi wewenang untuk membatasi hak - hak dasar sesuai dengan fungsi pengendalian (sturing). Jadi walaupun hak - hak dasar mengandung sifat membatasi kekuasaan pemerintahan, pembatasan tersebut tidak berarti mematikan kekuasaan pemerintahan yang pada dasarnya berisi wewenang untuk mengendalikan kehidupan masyarakat. Berdasarkan hal tersebut, sehubungan dengan pengendalian kehidupan, konsep Negara hukum Indonesia tidak dapat terlepas dari pengaturan Hak Asasi itu sendiri khususnya dalam ground norm yakni Undang - Undang Dasar Negara Republik Indonesia Amandemen IV(UUD 1945).

Upaya demokratisasi dan kebebasan warga Negara harus terus dilakukan pembenahan dan penyempurnaan dalam menyeimbangkan dan menyelaraskan dengan tututan demokrasi secara kontemporer. Hal ini dikarenakan kebutuhan atas konsepsi demokrasi tersebut dari waktu ke waktu memang harus selalu disesuaikan dengan kebutuhan kekinian yang berbasis kepada kepentingan Negara dan warga Negara dan menciptakan konsep demokrasi dan kebebasan warga Negara ke depan.

\section{Kasus / Masalah}

1) Bagaimana cara menegakkan HAM?

2) Apa hambatan dalam penegakan demokrasi?

3) Apa hubungan antara HAM dan demokrasi?

\section{Tinjauan Pustaka}

Asal usul gagasan mengenai hak asasi manusia dapat diruntut kembali sampai jauh kebelakang hingga ke zaman kuno dengan filsafat Stoika hingga ke zaman modern. Di kalangan para ahli hukum terdapat tiga teori utama yang menjelaskan asal muasal lahirnya pemikiran mengenai hak asasi manusia, yaitu :

a) Teori Hukum Kodrati

Teori hukum kodrati melihat hak asasi lahir dari Tuhan sebagai bagian dari kodrat manusia. Ketika manusia lahir sudah melekat dalam dirinya sejumlah hak yang tidak dapat diganti apalagi dihilangkan, apapun latar belakang agama, etnis, kelas sosial, dan orientasi seksual mereka. Teori hokum kodrati menurut ahli :

- John Locke mengajukan sebuah postulasi pemikiran bahwa semua individu dikaruniai oleh alam hak yang melekat atas hidup, kebebasasan dan kepemilikan, yang merupakan milik mereka sendiri dan tidak dapat dicabut oleh Negara. Melalui suatu - kontrak sosial (social contract), perlindungan atas hak yang tidak dapat dicabut ini diserahkan pada Negara. Apabila penguasa Negara mengabaikan kontrak social itu dengan melanggar hak-hak kodrati individu, maka rakyat di Negara itu bebas menurunkan sang penguasa dan menggantinya dengan suatu pemerintah yang bersedia menghormati hak - hak tersebut.

- Rousseau mengatakan bahwa hukum kodrati tidak menciptakan hak - hak kodrati individu, melainkan hak kedaulatan warga Negara sebagai suatu kesatuan. Setiap hak yang diturunkan dari suatu hukum kodrati akan ada pada warga Negara sebagai satu kesatuan yang bisa diidentifikasi melalui kehendak umum (general will). 
b) Teori Positivisme atau Utilitarian

Dalam pandangan teori positivisme hak barulah ada jika ada hukum yang telah mengaturnya. Moralitas juga harus dipisah secara tegas dalam dimensi hukum. Adapun kepemilikan hak dari tiap individui bisa dinikmati apabila diberikan secara resmi oleh penguasa atau Negara. Dan yang paling menonjol dalam pandangan ini ialah mempriorotaskan kesejahteraan mayoritas. Sedangkan kelompok minoritas yang preferensinya tidak diwakili oleh mayoritas bisa diabaikan dan kehilangan hak - haknya.

c) Teori Keadilan

Dalam pandangan Rawls, tiap orang memiliki hak yang di dasarkan pada konsep keadilan yang tidak bisa di tawar, karena hal tersebut terkait dengan isu kesejahteraan masyarakat secara umum. Untuk itu, keadilan akan terwujud apabila didasarkan pada prinsi - prinsip "posisi asali" nya masing - masing. Dalam keadaan ini tiap orang akan diasumsikan memilih dua prinsip keadilan pokok. Prinsip pertama, tiap orang akan diberikan hak yang sama luasnya. Prinsip kedua adalah kesetaraan yang di dasarkan pada kompetisi yang adil dan hanya dijustifikasi bila ia menguntungkan bagi pihak yang paling di rugikan. Bila diantara keduanya mengalami pertentangan maka kebebasan yang setara harus dimenangkan dari kesempatan yang setara. Pilihan atas kedua prinsip ini, menurut Rawls akan mengemuka karena para pihak yang mengadakan kontrak berada dalam "keadaan tanpa pengetahuan" atau tidak tahu berbagai fakta yang akan menempatkan posisi kita di suatu masyarakat.

Ketiga teori diatas memiliki persamaan dalam hal pengakuan, perlindungan dan penghormatan terhadap hak asasi manusia. Perbedaannya terletak pada pandangan mengenai asal muasal lahirnya hak yang paling mendasar tersebut.

Dasar Teori Demokrasi versi Hans Kelsen, awal dari datangnya ide demokrasi menurut Hans Kelsen adalah adanya ide kebebasan yang berada dalam benak manusia. Pertama kali, kosakata "kebebasan" dinilai sebagai sesuatu yang negatif. Pengertian "kebebasan" semula dianggap bebas dari ikatan - ikatan atau ketiadaan terhadap segala ikatan, ketiadaan terhadap segala kewajiban. Namun, hal inilah yang ditolak oleh Hans Kelsen. Pasalnya, ketika manusia berada dalam konstruksi kemasyarakatan, maka ide "kebebasan" tidak bisa lagi dinilai secara sederhana, tidak lagi semata - mata bebas dari ikatan, namun ide "kebebasan" dianalogikan menjadi prinsip penentuan kehendak sendiri. Inilah yang kemudian menjadi dasar pemikiran Hans Kelsen mengenai demokrasi. (Hans, 2006: 404).

\section{Pembahasan}

Hak Asasi Manusia dan Demokrasi tidak dapat dipisahkan. Demokrasi yang memperjuangkan hak atas kebebasan menyatakan pendapat, berserikat dan berpartisipasi aktif dalam menentukan penyelenggaraan negara merupakan bagian dari Hak Asasi Manusia juga. Saat ini pelaksanaan HAM di Indonesia dianggap kurang terlaksana dengan baik. Kasus kasus yang terjadi di Indonesia seperti penanganan Aceh, Timor Timur, Maluku, Poso, Papua, Semanggi, dan Tanjung Priok dianggap sebagai pelaksanaan perlindungan Hak Asasi Manusia yang belum berjalan. Upaya pendekatan keamanan dengan mengutamakan upaya represif menghasilkan keamanan yang sangat stabil namun dianggap banyak sekali 
menimbulkan terjadinya pelanggaran HAM, hal ini tidak boleh terulang kembali, untuk itu supremasi hukum dan demokrasi harus ditegakkan, pendekatan hukum dan dialogis harus dikemukakan dalam rangka melibatkan partisipasi masyarakat dalam kehidupan berbangsa dan bernegara. Perlunya lebih memberikan Desentralisasi melalui otonomi daerah dengan penyerahan berbagai kewenangan dari pemerintah pusat kepada pemerintah daerah. Supremasi hukum harus ditegakkan, sistem peradilan harus berjalan dengan baik dan adil, para pejabat penegak hukum harus memenuhi kewajiban tugas yang dibebankan kepadanya dengan memberikan pelayanan yang baik dan adil kepada masyarakat pencari keadilan, memberikan perlindungan kepada semua orang menghindari tindakan kekerasan yang melawan hukum dalam rangka menegakkan hukum. Perlunya social control dan lembaga politik dalam upaya penegakan HAM yang dilakukan oleh pemerintah.

Demokrasi merupakan sebuah bentuk sistem politik suatu negara dan juga merupakan budaya politik suatu bangsa. Demokratisasi pada suatu sistem pemerintahan melalui proses yang tidak mudah. Pada saat perubahan terjadi, selalu ada orang yang tidak ingin melakukan perubahan terus menerus, atau ada manusia yang tidak mampu menyesuaikan diri dalam kontes demokratisasi, peran individu yang mampu menerima perubahan itu sangat penting. Untuk itulah, individu harus punya tanggung jawab. Apalagi globalisasi yang terus mendorong perubahan yang tidak bisa ditahan oleh Negara manapun. Demokratisasi biasanya terjadi ketika ekspektasi terhadap demokrasi muncul dari dalam Negara sendiri, karena warga negaranya melihat sistem politik yang lebih baik, seperti yang berjalan di negara demokrasi lain yang telah mapan, akan bisa juga dicapai oleh Negara tersebut. Dengan kata lain, pengaruh internasional datang sebagai sebuah inspirasi yang kuat bagi warga Negara di dalamnya.

Apa yang terjadi di Indonesia saat ini cenderung adanya "distorsi" pemahaman pluralisme yang tidak bersesuaian dengan pemahaman jati diri bangsa yang sesungguhnya. Hal ini yang justru mendorong timbulnya konflik ketegangan di tengah kehidupan pluralitas bangsa Indonesia yakni: konflik yang diakibatkan perbedaan pandangan antar masyarakat maupun masyarakat dengan negara mengenai demokrasi, konflik yang timbul dengan membawa kecenderungan disintegrasi dengan faktor kompleks seperti masalah ketidak adilan di bidang ekonomi, politik, sosial, agama, budaya, dan hukum, ketegangan primordial yang kurang terjembatani dalam jangka waktu yang lama; otokrasi pemerintahan, keteladanan para pemimpin politik, agama dan tokoh masyarakat yang semakin merosot, semuanya itu menyumbang dan memperparah berbagai konflik yang terjadi di tengah - tengah masyarakat.

Manusia sebagai makhluk sosial dalam kehidupan sehari - hari pasti membutuhkan manusia lain. Demikian pula manusia sebagai makhluk individu sangat membutuhkan Negara untuk tempat bernaung. Hubungan antara Negara dan masyarakat memberi gambaran penyerahan sebagian hak masyarakat kepada Negara yang diwujudkan dengan bentuk kepatuhan masyarakat untuk menjalankan serangkaian kewajiban yang dibebankan negara kepadanya. Sementara negara memiliki kewajiban untuk memenuhi hak - hak warga negaranya, sebagai kompensasi dari kepatuhan masyarakat. Jadi wajar jika masyarakat menuntut negara jika hak - hak asasi masyarakat tidak dipenuhi oleh negara. Negara dalam merealisasikan hak asasi warga negaranya sebagaimana yang diatur dalam peraturan perundang - undangan, karena jika negara ataupun masyarakat ada yang melanggar hak asasi 
maka terdapat sanksi tegas yang ada dalam peraturan perundang - undangan yang telah disepakati bersama.

Sebagai sesama manusia sudah seharusnya saling menghormati dan menghargai Hak Asasi yang dimiliki, tidak hanya sesama manusia tetapi juga masyarakat dan Negara. Maka sebuah Negara memiliki kewajiban untuk mengeluarkan peraturan perundangan dan hukum lainnya yang dapat menjamin Hak Asasi Manusia seluruh warga negaranya, tidak hanya menguntungkan salah satu pihak. Negara juga tidak boleh mencampuri dan atau menghalang - halangi masyarakat dalam upaya pemenuhan hak asasinya.

\section{Kesimpulan}

Hak Asasi Manusia dengan demokrasi tidak dapat dipisahkan, karena dalam upaya penegakan demokrasi harus menghormati, menghargai, dan menjunjung tinggi HAM yang dimiliki warga negaranya. Maka, bila salah seorang ataupun Negara melanggar HAM, pasti ada sanksi tegas yang berlaku. Begitu juga sebaliknya, sebagai warga Negara yang baik sudah seharusnya membantu pemerintah dalam menegakkan demokrasi. Dalam upaya penegakan demokrasi tersebut pasti ada hambatan yang timbul seperti penolakan dari warga negaranya untuk menerima perubahan. Perlu pemikiran terbuka dari masyarakat dalam menerima sebuah perubahan, maka pemerintah harus menegakkan hukum dengan adil, bijaksana, dan sesuai dengan peraturan perundangan yang berlaku, juga sikap dari anggota penegak hukum yang harus sesuai dengan peraturan perundangan. Dengan begitu, masyarakat akan senantiasa membuka pikiran dan menerima sebuah perubahan. Maka dari itu perlu kontribusi dari berbagai pihak dalam penegakan demokrasi.

\section{Daftar Pustaka}

Amalia, F., \& Dewi, A. P. (2018). Hak Asasi Manusia dan Demokrasi di Indonesia. Media Keadilan: Jurnal Ilmu Hukum, 9(2), 172-187.

Asnawi, H. S. (2011). Politik Hukum Perlindungan Hak-Hak Asasi Manusia Kaum Perempuan Di Indonesia (Studi Tentang Upaya Mewujudkan Keadilan Dan Kesetaraan Gender Kaum Perempuan Di Bidang Kesehatan Era Pemerintahan Susilo Bambang Yudhoyono/SBY) (Doctoral dissertation, UNIVERSITAS ISLAM INDONESIA).

Besar, B. (2011). Pelaksanaan dan Penegakkan Hak Asasi Manusia dan Demokrasi di Indonesia. Humaniora, 2(1), 201-213.

Hebatullah, H. (2021). Pentingnya Tanggung Jawab Dalam Menjaga Persatuan Dan Kesatuan di Kehidupan Sehari-Hari.

Khairazi, F. (2015). Implementasi demokrasi dan hak asasi manusia di indonesia. INOVATIF| Jurnal Ilmu Hukum, 8(1).

Rosana, E. (2016). Negara demokrasi dan hak asasi manusia. Jurnal Tapis: Jurnal Teropong Aspirasi Politik Islam, 12(1), 37-53.

Siyoto, S., \& Sodik, M. A. (2015). Dasar metodologi penelitian. Literasi Media Publishing. 
Syam, F. (2011). Dilema Pluralitas: Hambatan Atau Penguatan Demokrasi Bangsa Indonesia. Jurnal Ilmu Hukum, 11(2), 1014.

Thalhah, H. M. (2008). Menyegarkan Kembali Pemahaman Teori Demokrasi Melalui Pemikiran Hans Kelsen. UNISIA, 31(69). 